\title{
PRZ index for identifying potential areas of recharge in alluvial aquifers and for land use planning
}

INGENIERÍA AMBIENTAL

\section{Índice ZPR para identificar áreas potenciales de recarga de acuíferos aluviales y para la planificación del uso del suelo}

\author{
María F. Jaramillo $^{1 \S}$ (i), Ruber Rengifo ${ }^{1}$ [i] , Inés Restrepo $^{1}$ (i) \\ ${ }^{1}$ Universidad del Valle, Facultad de Ingeniería, Instituto de Investigación y Desarrollo en \\ Abastecimiento de Agua, Saneamiento Ambiental y Conservación del Recurso Hídrico (CINARA), Cali, \\ Colombia

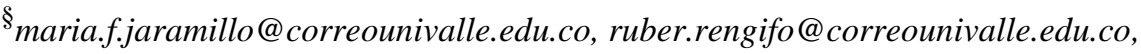
ines.restrepo@correounivalle.edu.co

Recibido: 10 de febrero de 2021 - Aceptado: 8 de julio de 2021

\begin{abstract}
An index to identify potential recharge zones (PRZs) in alluvial aquifers was developed to protect these zones during land use planning. The PRZ index was designed as an additive index through the selection of five characterization indicators. The variables were then operationalized and categorized to generate a conceptual model of the physicalgeological system. The PRZ index places recharge zones into four classes according to their potential. This index was applied to the Bolo River hydrogeological area (Valle del Cauca, Colombia), and the following proportions were identified for each PRZ category with a total area greater than $426 \mathrm{~km}^{2}$ : very high: $23 \%$, high: $30 \%$; moderate: $40 \%$ and low: $7 \%$. The areas with a very high recharge potential were found in the upper portion of the debris cones; their potential was predominantly due to the presence of sand and gravel unconfined aquifers and to aquifer outcrop layers at depths of less than $2.5 \mathrm{~m}$. These PRZs were validated with piezometry, and the hydraulic gradient for $71 \%$ of the area was greater than $1 \%$. These areas should be declared protected areas.
\end{abstract}

Keywords: additive index, alluvial aquifer, aquifer recharge, conceptual model, land use planning, Potential Recharge Zone (PRZ), natural recharge.

\section{Resumen}

Se desarrolló un índice para identificar posibles Zonas Potenciales de Recarga (ZPR) de acuíferos aluviales para la planificación del uso del suelo. El índice ZPR fue diseñado como un índice aditivo mediante la selección de cinco indicadores de caracterización. Las variables fueron operacionalizadas y categorizadas para generar un modelo conceptual del sistema físico-geológico. El índice PRZ clasifica las zonas de recarga en cuatro clases según su potencial. Este índice se aplicó al área hidrogeológica del río Bolo (Valle del Cauca, Colombia) con un área total de $426 \mathrm{~km}^{2}$. Se identificaron las siguientes proporciones para cada categoría de índice ZPR: Muy Alta: 23\%, Alta: 30\%; Moderada: $40 \%$ y Baja: $7 \%$. Las áreas con un potencial de recarga Muy Alto se encontraron en la parte superior de los Como citar:

Jaramillo MF, Rengifo R, Restrepo I. Índice ZPR para identificar áreas potenciales de recarga de acuíferos aluviales y para la planificación del uso del suelo. INGENIERÍA Y COMPETITIVIDAD. 2022;24(1):e21011001. https://doi.org/10.25100/iyc.v24i1.11001. 
conos aluviales; su potencial se debió principalmente a la presencia de acuíferos no confinados de arena y grava ya las capas de afloramientos del acuífero a profundidades inferiores a $2.5 \mathrm{~m}$. Estas zonas potenciales de recarga fueron validadas con piezometría y el gradiente hidráulico que para el $71 \%$ del área fue superior al 1\%. Estas áreas deben ser declaradas áreas protegidas.

Palabras clave: acuífero aluvial, modelo conceptual, planificación del uso del suelo, recarga de acuíferos, recarga natural, zonas potenciales de recarga $(P Z R)$.

\section{Introduction}

Groundwater supplies $50 \%$ of the world's population and represents $43 \%$ of the water used for irrigation ${ }^{(1)}$. According to UNESCO ${ }^{(1)}, 2500$ million people depend on this resource daily to satisfy their needs. As population growth increases, groundwater resources are under greater pressure, and $20 \%$ of aquifers are being overexploited. Being able to estimate aquifer recharge is critical for the integrated management of groundwater resources because it allows the design of priority areas for conservation. Spatially delimiting groundwater resources can be considered an initial approach in obtaining a greater knowledge of the general dynamics of water ${ }^{(2)}$.

Any study involving water resources, particularly studies involving issues such as the transport of pollutants, subsidence processes, and the disposal and reuse of liquid effluents in soils, should include the identification and quantification of recharge ${ }^{(3)}$. Therefore, understanding and quantifying recharge processes is required to analyze water resource sustainability and to provide basic information for land-use decisions (4). However, many human activities such as agriculture, livestock, forestry production, urban development, industry and the disposal of wastewater (treated and untreated) in soils alter the characteristics of natural water recharge zones and interfere with water infiltration ${ }^{(5)}$.

Physically, aquifer systems are fed naturally through their recharge zones, which are areas with geological, edaphic, and climatic characteristics that facilitate the infiltration and movement of water toward saturation zones. In this regard, recharge zones have been defined as areas of special importance because they present the greatest input of water to aquifer systems ${ }^{(6-10)}$ and are potential sources of water for human consumption and other economic activities. To protect aquifers from becoming contaminated, it is necessary to restrict current and future land-use practices, the discharge of liquid effluents, and the dumping of waste in recharge areas ${ }^{(11)}$.

Regarding the design and application of methodologies for evaluating aquifer recharge zones, studies carried out in India identified the recharge zones of an aquifer in an urban settlement using environmental isotopes $(2 \mathrm{H}, 3 \mathrm{H}$, $18 \mathrm{O})$ that were correlated with hydrogeological conditions. The mapping of potential recharge areas was based on the soil type and the depth of the water table. Hydrogeological evidence was used to approximate the spatial distribution of permeable zones, slopes, and boundary conditions, which was validated isotopically ${ }^{(12)}$. In another Indian study, a technique was developed to delimit artificial recharge zones by integrating remote sensors and geographic information systems (GIS) to increase the scarce groundwater reserves west of the Medinipur district of West Bengal ${ }^{(10)}$.

In the Aguascalientes Valley, Mexico, a methodology was developed to identify areas with the potential to be naturally recharged by aquifers. The researchers applied a multi-criteria process with GIS in areas of high geological heterogeneity located in three geological provinces: the Sierra Madre Occidental, the Mesa Central, and the Trans-Mexican Volcanic Belt. The study area presented different outcroppings of acidic extrusive igneous, intrusive igneous, continental, and marine sedimentary, metamorphic and sedimentary rocks. Information on the lithology, precipitation, drainage density, 
vegetation cover, land use, and topography was analyzed $^{(13)}$.

The environmental isotopes $2 \mathrm{H}, 18 \mathrm{O}$ and $3 \mathrm{H}$ have been used to identify possible sources and recharge areas in Colombia in the Bajo Cauca Antioquia aquifer, which is geologically associated with recent alluvial deposits of the Cauca River's main channels and its tributaries and the upper and lower members of the Cerrito sedimentary formation ${ }^{(14)}$.

At the end of the 1990s, in the study area, the Environmental Authority (CVC) ${ }^{(15)}$ determined the regional groundwater flow system in the Cauca River valley, based on the water level of 1200 constructed wells. From which, the piezometric head and the hydraulic gradients were determined, to preliminarily delineate the recharge and discharge areas of the regional aquifer.

In 2015, a conceptual model of the aquifer was validated; the diffuse recharge was estimated using a methodology based on the hydrometeorological balance of the subsoil at a resolution of $250 \times 250 \mathrm{~m}$. The calculated average multiyear recharge was $3840 \mathrm{~km}^{3} /$ year (597 $\mathrm{mm} /$ year) ${ }^{(16)}$. This estimate was made for the management and use of groundwater in Cauca River valley.

Based on this scenario, the development of methods for delimiting recharge areas, which can be used to inform the organized and sustainable use of a territory, is considered a significant contribution to the management of groundwater resources. The objective of this research was to develop a methodological tool to evaluate the potential recharge zones (PRZs) in alluvial aquifers, due to the importation of these areas in the land use planning. The Bolo River hydrogeological area in the department, Colombia, was taken as a case study. An additive type index processed using GIS tools that consider the local hydrogeological environment at a detailed scale $(1: 25000)$ was developed. This research was conducted using the groundwater resource database of the Environmental Authority, which has been monitoring the aquifer since $1970^{(17)}$.

\section{Methodology}

\subsection{Study area}

The study area was delimited according to the geology ${ }^{(18)}$ and the surface drainage network ${ }^{(19)}$ in the Bolo River hydrogeological area, Colombia. The study area is located in the CaucaPatía hydrogeological province and the upper Cauca river basin surface system, between the coordinates $860000 \mathrm{~N}-1065000 \mathrm{E}$ and $885000 \mathrm{~N}$ 1100000E (Magna-Colombia-West reference system). The area covers approximately $426 \mathrm{~km}^{2}$ (Figure 1). The limits of the study area are as follows: to the north, the Palmira River; to the south, the Párraga River; to the west, the Cauca River; and the east, a volcanic formation.

The predominant slope in the study area varies from $7 \%$ to $12 \%$, with an inclined topography covering $61 \%\left(261.5 \mathrm{~km}^{2}\right)$ of the area, followed by slightly inclined areas (3-7\%) and strongly inclined areas (12-25\%) accounting for $29 \%$ $\left(123.9 \mathrm{~km}^{2}\right)$ and $9 \%\left(38.4 \mathrm{~km}^{2}\right)$ of the total area, respectively ${ }^{(20)}$.

Regarding groundwater management, the area has 450 wells, of which $74 \%$ are active and $26 \%$ are abandoned or inactive ${ }^{(17)}$. The flows and volumes of water extracted for the different uses are presented in Table 1, which shows that $84 \%$ of the water is used for crop irrigation, while $0.5 \%$ is used for drinking water and domestic use ${ }^{(17)}$.

Geologically and stratigraphically, the study area has the characteristics of an intermontane valley originating from the Cauca River between the central and western mountain ranges and over a narrow valley of tectonic origin. In its origins during the Neogene, this valley was formed in a 

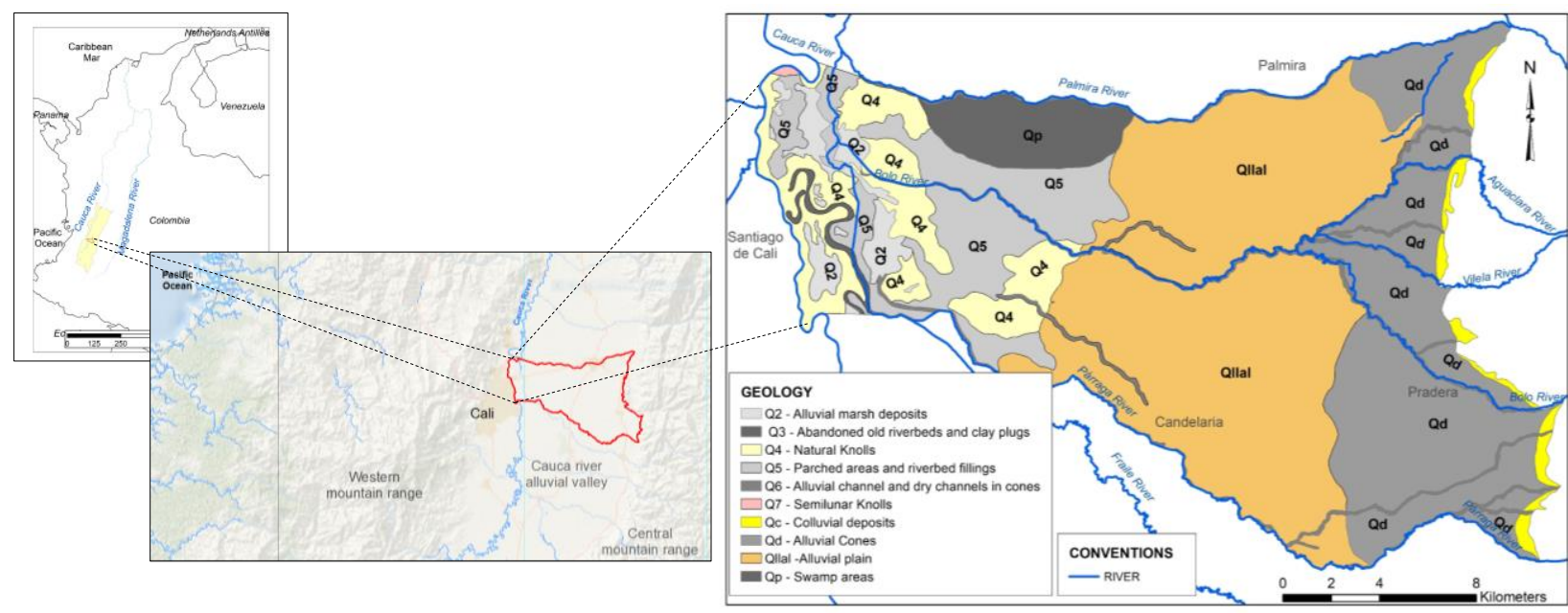

Figure 1. (a) General location. (b) Geology of the Bolo River hydrogeological area. Source: own elaboration

Table 1. Groundwater management indicators in the study area

\section{Groundwater uses}

\section{Management indicators}

\section{Industrial Domestic Agricultural Other}

\begin{tabular}{lcccc}
\hline Number of wells & 45 & 21 & 207 & 60 \\
Well percentage (\%) & 13.5 & 6.3 & 62.2 & 18.0 \\
Flow granted (1/s) & 694.79 & 100 & 15,719 & 2,293 \\
Flow percentage (\%) & 4 & 0.5 & 83.6 & 12.2 \\
Volume extracted (km 3 year) & 11.62 & 1.24 & 267.28 & 32.63 \\
Volume percentage (\%) & 4 & 0.4 & 85.5 & 10.4 \\
\hline from $^{(17)}$.
\end{tabular}

Source: adapted from ${ }^{(17)}$.

tectonically active intracordilleran basin, which has received fluvial and volcanic sedimentation from the central and western mountain ranges ${ }^{(21)}$. According to hydrogeological studies, the basement and the geologycal fault region are $1000 \mathrm{~m}$ deep.

\subsection{Design of the PRZ index}

The PRZ index was developed as an additive index based on criteria for the categorization and operationalization of variables recommended by Cazau ${ }^{(22)}$, Caparó ${ }^{(23)}$ and Reguant and Martínez (24). In an additive index, all the characterization indicators (i.e., the factors involved in the recharge process) have equal weight in the system and are not conflicting ${ }^{(25)}$.

The first step for the construction of the additive index consisted of developing the conceptual model associated with the definition of a PRZ in an alluvial aquifer. For this, the physical recharge process was diagrammed to identify the intervening indicators in the system. The indicators were identified through a review of the scientific literature using the following search terms: recharge zones, criteria for the delimitation of a PRZ, aquifer recharge and evaluation of recharge zones. The second step involved the selection process for the indicators, 
which was carried out based on consultations with 62 bibliographic references as well as local experts. The third step consisted of the categorization process of each indicator, which involved assigning categories using value ranges. For this, each indicator took on a value between 0 and 1 , with 1 being a zone with a greater recharge potential and 0 being a zone with no recharge potential. The categories assigned to each indicator were based on expert knowledge and a literature review. Once the indicators were categorized, the value of the PRZ index corresponded to the sum of the characterized indicators. The maximum value of the index is $\boldsymbol{n}$, which corresponds to the number of selected and characterized indicators. The PRZ were categorized by the PRZ index presented in Table 2.

Table 2. Categorization of the PRZ index

\begin{tabular}{cc}
\hline $\begin{array}{c}\text { Potential of the } \\
\text { recharge zone }\end{array}$ & $\begin{array}{c}\text { Value of the PRZ } \\
\text { index }\end{array}$ \\
\hline Very high & $4-5$ \\
High & $3-4$ \\
Moderate & $2-3$ \\
Low & $<2$ \\
\hline
\end{tabular}

Source: own elaboration

\subsection{Implementation of the $P R Z$ index in the hydrogeological area of the Bolo River, Colombia}

Based on the physical model of the system and the PRZ index, the study area was characterized using map algebra in the ArcGIS 10.2 software. To generate the map of each indicator, a spatial database was created with the plane coordinate system (MAGNA-SIRGAS-Colombia-West projection system) of 234 existing deep wells. To generate the maps of the indicators I1- Aquifer roof, I2 - Lithological Predominance of the Unsaturated Zone (USZ) and I4 - Degree of Confinement, an interpolation process was performed using the topo-to-raster tool in the
ArcGIS 10.2 toolbox, which uses an iterative finite difference interpolation technique.

The main advantage of this approach compared to other methods is its ability to correlate data with a topographic surface ${ }^{(26)}$. The characterization process of the indicators that constitute the designed PRZ index is described below:

$\checkmark \quad$ Indicator I1 - Aquifer roof: performed based on the lithological column of each well (17), in which the depth (in meters) of the roof of the first aquifer layer was identified from the ground surface.

$\checkmark \quad$ Indicator I2 - Lithological Predominance of the USZ: performed based on the predominant textural class of the lithological profile of each well from the topographic surface to the roof of the first aquifer layer. The information was obtained from the CVC databases ${ }^{(17)}$.

Indicator I3 - Lithological Predominance of the Saturated Zone (SZ): a correlation between the surface geology map ${ }^{(18)}$ and the predominant texture in the SZ of each well was determined by assigning the predominant textural group shown in Table 3 to each existing well.

The textural group of the well's lithological profile, with a length of approximately $100 \mathrm{~m}$ from the water level to the roof of unit $B$ of the alluvial aquifer ${ }^{(18)}$, was identified. Subsequently, each polygon of the surface geology was assigned the highest proportion of area with respect to the reclassified texture. For this, Thiessen polygons were generated. Once the indicator maps were obtained, the additive process was performed with the ArcGIS 10.2 tool, and thus, the PRZ index map in the hydrogeological zone in the area 
Table 3. Predominant texture in the $S Z$

\begin{tabular}{cl}
\hline $\begin{array}{c}\text { Predominant } \\
\text { textural group }\end{array}$ & \multicolumn{1}{c}{ Description } \\
\hline G1 & $\begin{array}{l}\text { The predominance of thick layers of permeable strata composed of gravels of medium to } \\
\text { coarse grain and the presence of rounded boulders (diameters greater than one meter). } \\
\text { Grevalence of permeable layers of sand and gravel of medium to coarse grain with the } \\
\text { presence of loamy soils and clayey-silt soils. }\end{array}$ \\
G3 & $\begin{array}{l}\text { Homogeneous and alternating permeable layers of sand and gravel with clayey and silty } \\
\text { lenses. } \\
\text { The predominance of a clay matrix with few alternating sand lenses and gravels of medium } \\
\text { to coarse grain. }\end{array}$ \\
\hline
\end{tabular}

Source: own elaboration

surrounding the Bolo River was estimated. This map was converted again to a polygon file for area-based estimates, and the data were later categorized into the four PRZ index types (Very High, High, Moderate and Low).

\subsection{Validation of the $P R Z$ index based on the hydraulic gradient}

The PRZ estimated for the study area was compared with the hydraulic gradient obtained from the piezometric surface based on the average piezometric level of each well, which was measured biannually from 2000 to $2015^{(17)}$. The piezometric levels were interpolated using the topo-to-raster tool. The isopiezometric contours were traced every five meters. The recharge zones identified by tracing the piezometric surface are characterized by high hydraulic potential values and downward and divergent flow ${ }^{(27)}$.

\section{Results}

\subsection{PRZ Index}

The process of selecting indicators for developing the PRZ index was based on a literature review (Table 4), preselecting those indicators with a citation percentage higher than $15 \%$ with respect to the consulted authors. Once the preliminary indicators were defined, the criterias were selected in a workshop with local experts. The selected indicators only correspond to parameters intrinsic to the aquifer system. Land cover, management practice and climate indicators were not selected because they are considered external factors to the recharge potential process and can be affected by climate variability, climate change and anthropic decisions.

The indicators related to water level depth, water table depth, aquifer roof and outcrop were grouped into "Aquifer roof" because this concept correlates with the other indicators in its definition. The indicators "soil texture" and "slope" were grouped within "infiltration potential" through the Hydrological Group concept. To avoid redundancy, "porosity" and "permeability" were excluded because they were already represented in the textural classes of the USZ and SZ lithological profiles and the edaphic zone. Table 5 summarizes the selected indicators and their definition.

The conceptual model for the definition of the PRZ index was based on the movement of water from the soil surface to the base of the first aquifer unit. This process distinguished the unsaturated zone (USZ) from the topographic surface to the water level (including the edaphic zone) and the saturated zone (SZ) that starts at the water level to the roof of the confining layer. In the vertical axis, the movement of water begins with the infiltration process on the ground surface to the groundwater level. The horizontal axis shows the surface geology units (Figure 2). The diagram of the conceptualized PRZ index is presented in Figure 3 , showing the five indicators selected and characterized in the study area and the index equation. 
Table 4. Literature review for the selection process of the characterization indicators

\begin{tabular}{|c|c|c|}
\hline Indicator & Author(s) & $\begin{array}{c}\text { Citation } \\
\text { percentage }\end{array}$ \\
\hline Degree of fracturing & $(28,29)$ & 3 \\
\hline Aquifer outcrop & $(2,30)$ & 3 \\
\hline Aquifer roof & $(4,29,31-35)$ & 11 \\
\hline Soil texture & $(2,28,29,31-33,36-67)$ & 63 \\
\hline Ground cover & $(2,28,34,37,38,41,48-50,68,69)$ & 18 \\
\hline Slope & $(28,34,35,37,38,40,41,45,46)$ & 16 \\
\hline Lithology USZ & $(2,28,29,31-35,37,39,48,49,56,58,59,62,64,65,67,69-75)$ & 40 \\
\hline Lithology SZ & $(2,28,29,31,32,34,35,37,48,49,56,58,59,62,64,65,67,69,71-75)$ & 35 \\
\hline Type of rock & $(29,31,33,37,47)$ & 8 \\
\hline $\begin{array}{c}\text { Soil management } \\
\text { practices }\end{array}$ & $(28,34,37,38,41,47,48,50-53,68,69,74,76,77)$ & 26 \\
\hline Geology & $(29,38,44,78)$ & 6 \\
\hline Infiltration potential & $(29,31-34,36,40,41,45-49,51,53,55,56,58,60,62-68,71,74,76,79)$ & 48 \\
\hline Climate & $(34-36,39,41,42,44,45,47,78,80)$ & 19 \\
\hline Elevation & $(2,29,34,41,45)$ & 10 \\
\hline Degree of confinement & $(29,31-34,48,64,70,75,81,82)$ & 18 \\
\hline Permeability & $(4,29,31,33,34,37,38,40-42,44,46,48,50-55,57,60,63,66,67,83,84)$ & 42 \\
\hline Porosity & $(4,29,31-34,38,40-42,46,48,50-55,57,60,63,66,67,83,84)$ & 40 \\
\hline Runoff & $(33,36,40,42,46,47)$ & 10 \\
\hline Hydraulic gradient & $(11,27,29,31-34,71,85)$ & 15 \\
\hline Magnitude of recharge & $(29,35,39)$ & 5 \\
\hline
\end{tabular}

Source: own elaboration

Table 5. Results of the selection of indicators for the design of the PRZ index

\begin{tabular}{ll}
\hline \multicolumn{1}{c}{ Indicator } & \multicolumn{1}{c}{ Definition of the indicator } \\
\hline Depth of the aquifer roof (I1) & $\begin{array}{l}\text { Depth at which the first permeable layer is found, measured from } \\
\text { the ground surface. } \\
\text { Physical characteristics of the materials of the medium that allow } \\
\text { the movement of water, referring to the lithology that indirectly } \\
\text { relates the effective porosity, permeability and moisture content } \\
\text { (only for the USZ). }\end{array}$ \\
$\begin{array}{l}\text { Lithological predominance of } \\
\text { USZ (I2) and SZ (I3) }\end{array}$ & $\begin{array}{l}\text { Hydraulic regime of the aquifer, associated with the accessibility of } \\
\text { water to the SZ and the direction of flow between the USZ and the }\end{array}$ \\
$\begin{array}{l}\text { Degree of hydraulic confinement } \\
\text { (I4) }\end{array}$ & $\begin{array}{l}\text { Physical characteristics of the materials of the edaphic zone (soil) } \\
\text { that facilitate water movement, referring to: texture, slope and } \\
\text { lithology. }\end{array}$ \\
\hline $\begin{array}{l}\text { Infiltration potential. Hydrological } \\
\text { group (I5) }\end{array}$ & \\
\hline
\end{tabular}

Source: own elaboration 


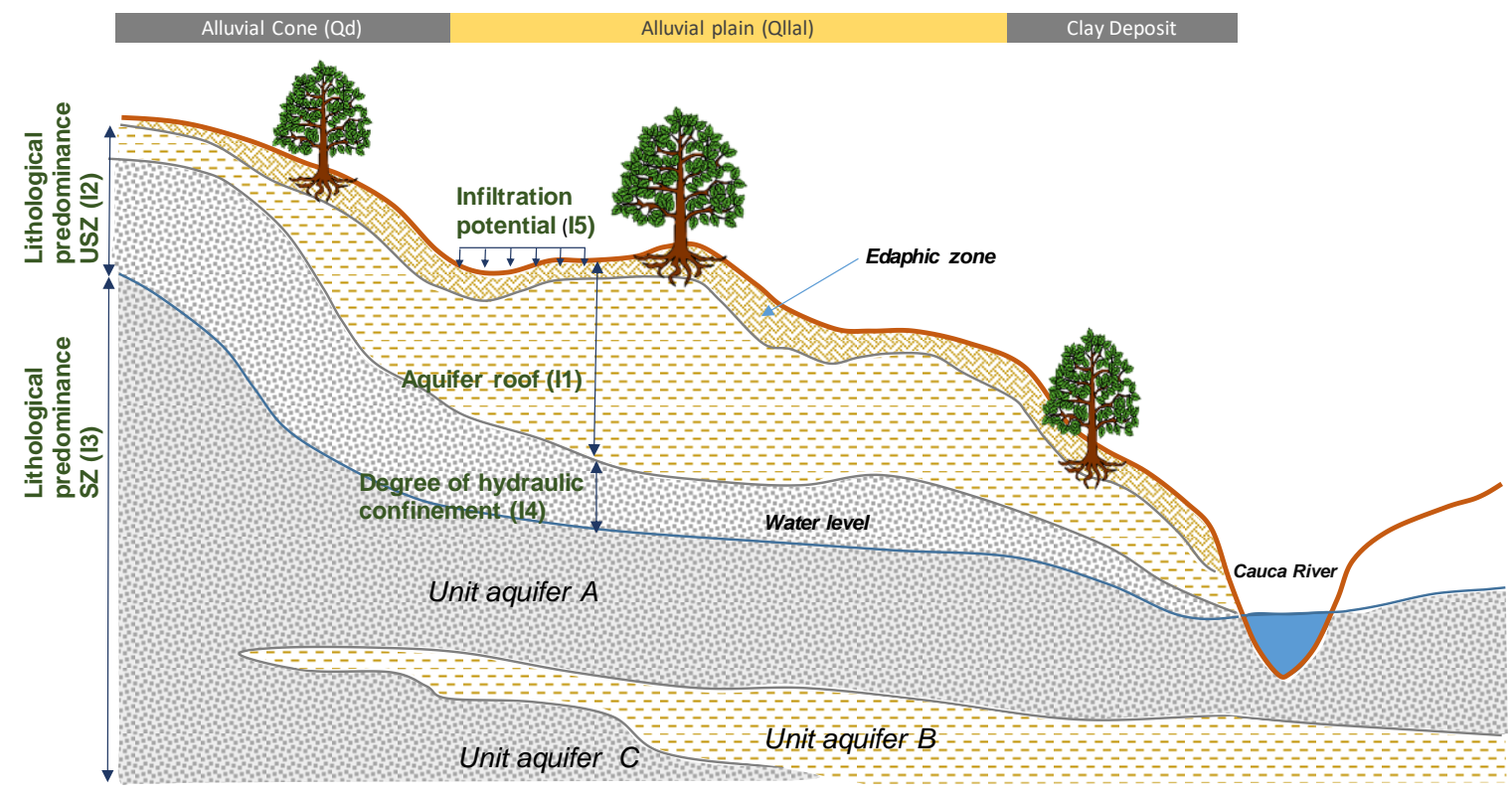

Figure 2. Conceptual model of the alluvial aquifer in the Bolo River hydrogeological area. Source: own elaboration

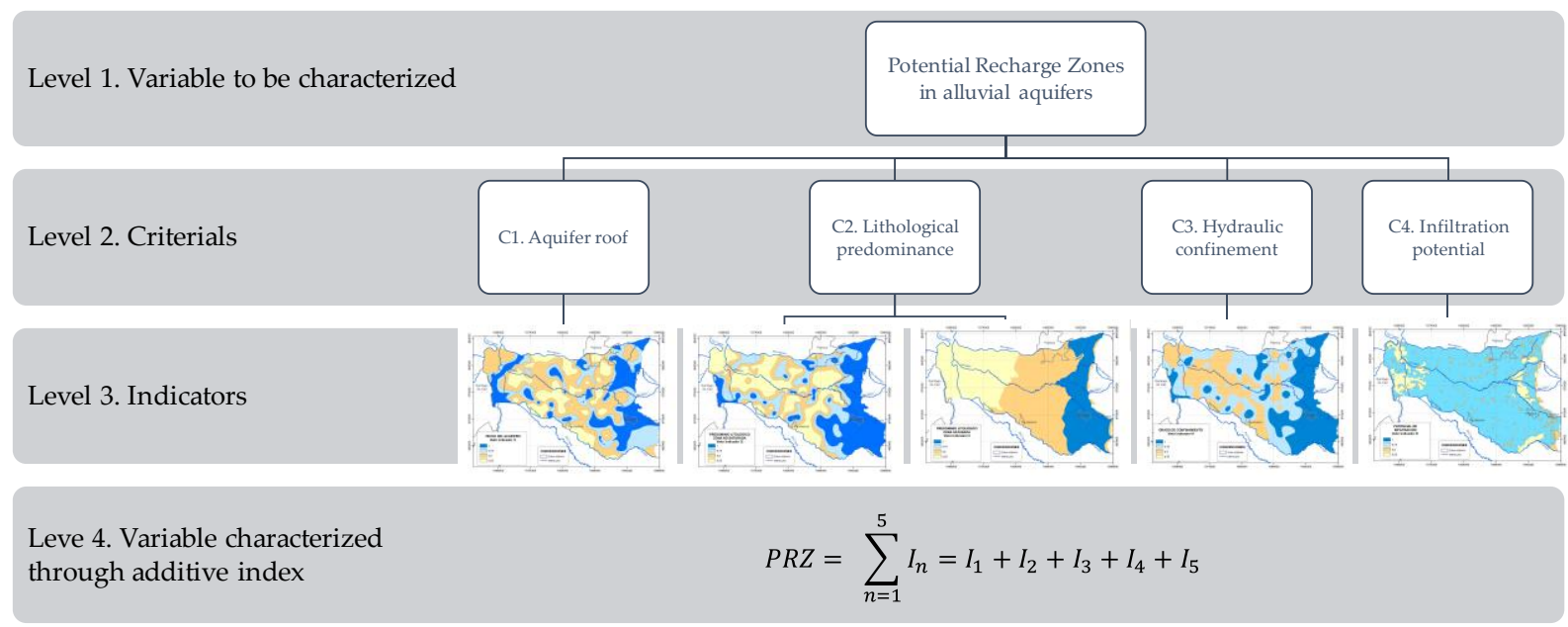

Figure 3. Conceptualization of the PRZ index according to Cazau. Source: adapted from ${ }^{(22)}$

\subsection{Implementation in the hydrogeological area of the Bolo River, Colombia}

The PRZs in the study area were delimited, and their results are presented in Table 6 and Figure 4. The areas categorized with very high recharge potential were $23 \%\left(97.07 \mathrm{~km}^{2}\right)$ of the area and are mainly in the upper part of the debris cones and, to a lesser extent, in focal areas of the midsection of the alluvial plain.
Table 6. Results of the categorization of the PRZs in the study area

\begin{tabular}{ccc}
\hline PRZ & Area $\left(\mathbf{k m}^{\mathbf{2}}\right)$ & $\begin{array}{c}\text { Percentage with } \\
\text { respect to \% area }\end{array}$ \\
\hline Very high & 97.07 & 22.79 \\
High & 126.64 & 29.73 \\
Moderate & 172.89 & 40.58 \\
Low & 29.43 & 6.91 \\
\hline
\end{tabular}

Source: own elaboration 


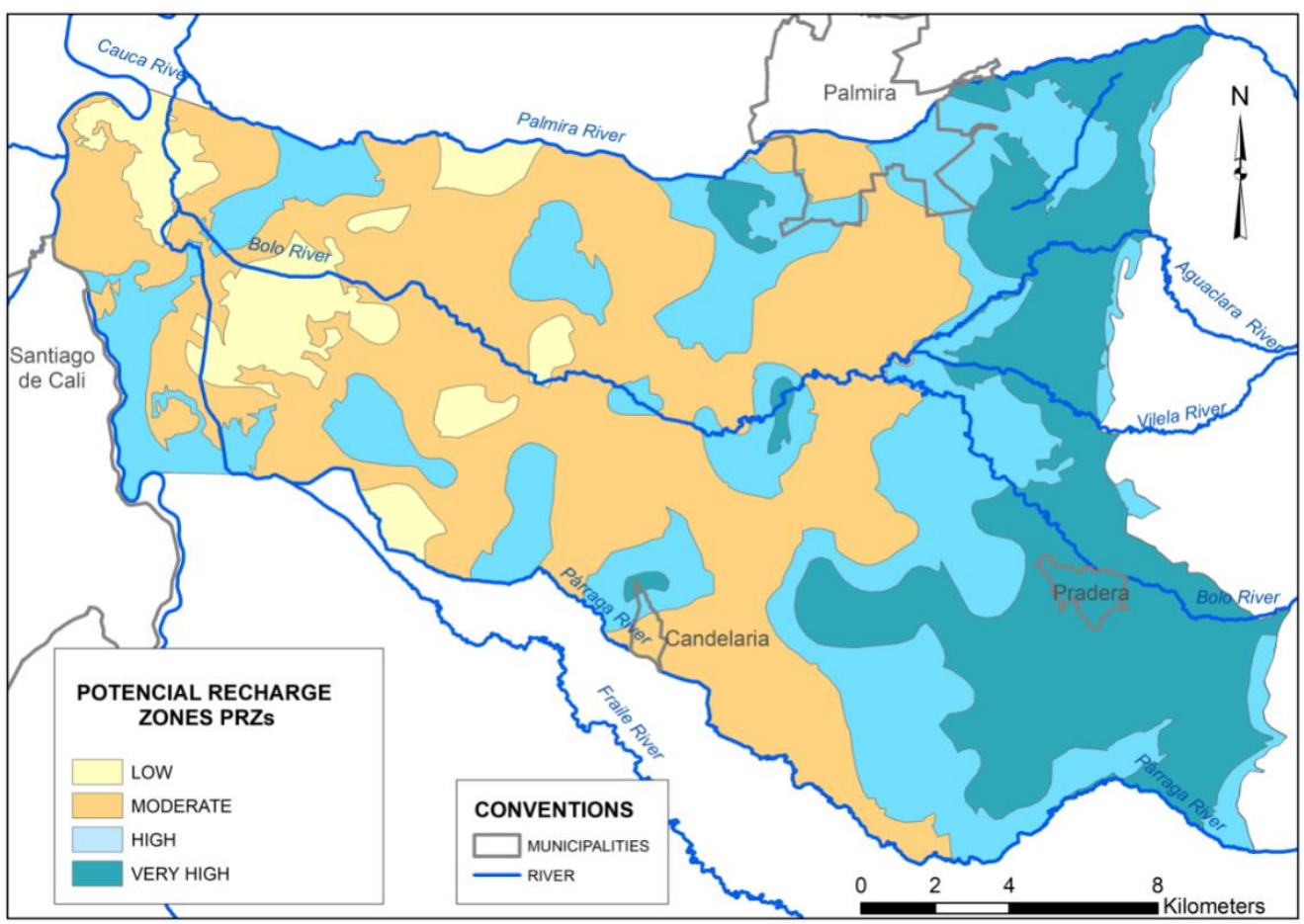

Figure 4. Spatial result of the PRZs in the study area. Source: own elaboration

This recharge potential was due to the presence of unconfined aquifers in $97 \%$ of its area and to the roof depth of the first permeable layer less than $2.5 \mathrm{~m}$, occurring in $64 \%$ of the area.

Regarding the lithological predominance of the NSZ, the areas with a very high recharge potential were characterized by the presence of permeable strata composed of sand, gravel and/or boulders. The lithological predominance of the SZ was characterized as group $\mathrm{G1}$, which corresponds to strata composed of sand, gravel and boulders, and accounted for over $84 \%$ of the area. The infiltration potential of this zone corresponded to hydrological group B for $83 \%$ of the area.

The zones with a high recharge potential represented $30 \%\left(126.64 \mathrm{~km}^{2}\right)$ of the study area and were located on the lower part of the debris cones. Some areas with equal potential were located in the middle and lower alluvial plain, and others were located toward the right bank of the Cauca River. The high potential of this area was due to the presence of $40 \%$ unconfined aquifers in
$60 \%$ of the area. The percentage of unconfined aquifers decreased with respect to the areas characterized by a very high potential. For this area, the depth of the roof of the first permeable layer was even deeper, between $2.5 \mathrm{~m}$ and $10 \mathrm{~m}$, in $75 \%$ of the area. The presence of a roof depth of less than $2.5 \mathrm{~m}$ decreased with respect to areas with a very high potential, reaching only $24 \%$ of the area. Regarding the lithological predominance of the USZ, the presence of sand-silts and intercalated sand, gravel and clay was found in $57 \%$ of this area.

Unlike the area with a very high potential, the most permeable strata only represented $29 \%$ of the area. The lithological predominance of the SZ corresponded to group $\mathrm{G} 3$, which corresponds to intercalated lenses of clay, sand and gravel in 56\% of the area. The infiltration potential corresponded to hydrological group B in $80 \%$ of the area, but the presence of hydrological groups $\mathrm{C}$ and $\mathrm{D}$ was observed in $7 \%$ and $13 \%$ of the area, respectively. 
Areas of moderate recharge potential were located over the entire alluvial plain and in the clay deposits toward the lower part of the study area, representing $40 \%$ of the total area (172.89 $\mathrm{km}^{2}$ ). In this area, the roof of the first permeable layer was further deepened and was greater than $5 \mathrm{~m}$ in $87 \%$ of the area. Regarding the lithology of the USZ, unlike the areas with very high and high potentials, the predominance of clay was observed in $52 \%$ of the area, and the predominance of silt and silt-clay was observed in $36 \%$ of the area. In contrast to this zone, the clay strata did not appear in the zone with a very high recharge potential. Regarding the lithological predominance of the SZ, it was characterized as

In the USZ lithology, clay predominated in 94\% of the area lacking permeable strata. The lithological predominance of the SZ was characterized as group G4 and was present in $99 \%$ of the area, and group G3 only accounted for $1 \%$ of the area. Regarding the infiltration potential, group G3, which corresponds to intercalated lenses of clay, sand and gravel in 57\% of the area, but a $43 \%$ less permeable stratum was classified in group G4. The infiltration potential corresponded to hydrological group B in $91 \%$ of the area; however, hydrological groups $\mathrm{C}$ and $\mathrm{D}$ were observed in $4 \%$ and $5 \%$ of the area, respectively.

The zones with a low potential represented 7\% $\left(29.43 \mathrm{~km}^{2}\right)$ of the study area and are located mainly on the clay deposits of the lower part of the basins of the Bolo, Párraga and Fraile Rivers. In this area, the deepest roofs of the entire study area were found below $10 \mathrm{~m}$ in $66 \%$ of the area.

hydrological group B predominated in $54 \%$ of the area. However, an increase in hydrological group D was observed, covering $43 \%$ of the area, and hydrological group C only corresponded to $3 \%$ of the area. Table 7 shows the indicators that predominated in each PRZ.

Table 7. Summary of the predominant indicators associated with each PRZ

\begin{tabular}{|c|c|c|c|c|c|}
\hline \multirow{2}{*}{ PRZ } & \multicolumn{5}{|c|}{ Percentage with respect to the PRZ } \\
\hline & I1 & I2 & I3 & I4 & $\mathbf{I 5}$ \\
\hline Very high & $63.6 \%$ & $95.6 \%$ & $84.1 \%$ & $97.2 \%$ & $83.4 \%$ \\
\hline $97.05 \mathrm{~km}^{2}$ & $<2.5 \mathrm{~m}$ & Sand, gravel and/or boulders & G1 & Unconfined & GH: B \\
\hline $\begin{array}{c}\text { High } \\
126.64 \mathrm{~km}^{2}\end{array}$ & $\begin{array}{c}41.07 \% \\
2.5-5.0 \mathrm{~m}\end{array}$ & $\begin{array}{c}57.3 \% \\
\text { Sandy silt and intercalated } \\
\text { sand, gravel and clay }\end{array}$ & $\begin{array}{c}56.3 \% \\
\text { G3 }\end{array}$ & $\begin{array}{l}59.6 \% \\
\text { Covered unconfined }\end{array}$ & $\begin{array}{l}79.9 \% \\
\text { GH: B }\end{array}$ \\
\hline Moderate & $54.1 \%$ & $51.8 \%$ & $57.4 \%$ & $51.3 \%$ & $90.4 \%$ \\
\hline $172.89 \mathrm{~km}^{2}$ & $5.0-10 \mathrm{~m}$ & Clay & G3 & Semiconfined & GH: B \\
\hline Low & $65.6 \%$ & $94.3 \%$ & $99.9 \%$ & $99.1 \%$ & $53.9 \%$ \\
\hline $29.43 \mathrm{~km}^{2}$ & $>10 \mathrm{~m}$ & Clay & G4 & Semiconfined & GH: B \\
\hline
\end{tabular}

Source: own elaboration

\subsection{Validation of the PRZ index based on the hydraulic gradient}

Regarding validation, it was observed through piezometry that the direction of the underground flow goes from the upper part of the Bolo, Aguaclara, Vilela and Párraga rivers to the Cauca River (east-west direction) (Figure 5a). For the entire study area, the hydraulic gradients showed a descending vertical behavior along the direction of flow, from the $1115 \mathrm{~m}$ piezometric line to the $945 \mathrm{~m}$ piezometric line. According to Freeze and Cherry ${ }^{(8)}$, According to the authors, the high areas are recharge areas and the low areas are discharge areas. However, Scanlon et al. stated that the above is true in humid regions. For arid alluvial valleys, recharge usually occurs in low topographies; this condition being similar to the 
study area of this research.A visual analysis of the piezometry in the upper part of the debris cones revealed the shortest distance between the isopleths with the maximum hydraulic gradient for the study area of between $2 \%$ and $3 \%$; consequently, the flow rate was higher here.

This behavior coincided with the zones characterized by very high and high potentiality (Figure 5a). In contrast, for the isopleths located farther away from the Cauca River, the distance between the piezometric lines increased, which was reflected in a decreased hydraulic gradient that reached values below $0.3 \%$; the flow velocity was therefore lower. This behavior coincided with the zones characterized by moderate and low recharge potentials (Figure 5a).

The relationship between the estimated hydraulic gradient and its spatial distribution and the PRZ results is presented in Figure 5b. For the areas characterized by a very high recharge potential, $71 \%$ of the area had gradients greater than $1 \%$ $\left(68.94 \mathrm{~km}^{2}\right)$. In this same gradient range, the zones characterized by a high potential accounted

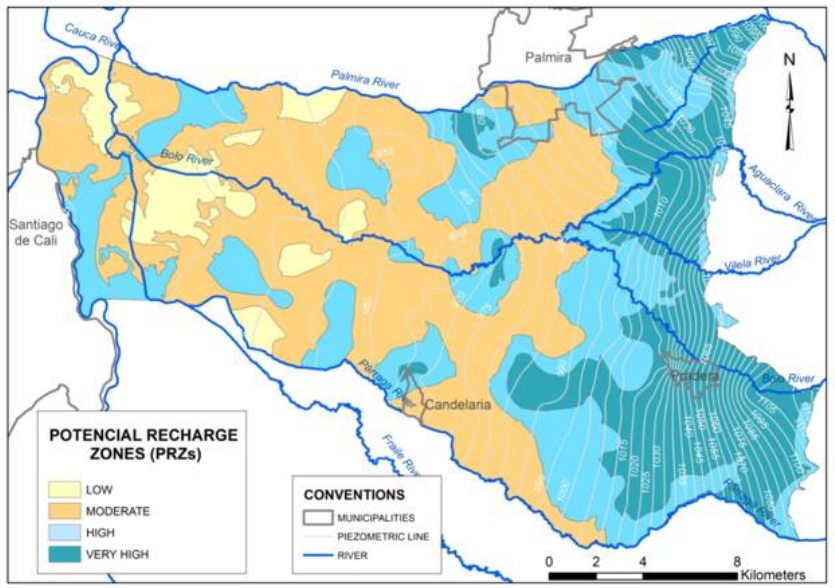

(a) for $18 \%$ of the area $\left(22.68 \mathrm{~km}^{2}\right)$ and $1 \%$ of the area $\left(1.07 \mathrm{~km}^{2}\right)$ corresponded to zones with a moderate potential.

For low recharge potential areas, the representativeness, in this hydraulic gradient range as a function of area, was zero. According to the above results, a direct relationship between hydraulic gradients greater than $1 \%$ and the presence of areas with high and very high recharge potentials was observed.

Regarding the higher representativeness of areas based on the range of hydraulic gradients, the pattern of recharge potential in the study area presented in Figure 6 is as follows: very high areas accounted for $55 \%$ of the area $\left(53.53 \mathrm{~km}^{2}\right)$ with a gradient range between $1 \%$ and $2 \%$; high zones accounted for $39 \%$ of the area $\left(48.76 \mathrm{~km}^{2}\right)$ with a gradient range between $0.5 \%$ and $1 \%$; moderate zones accounted for $48 \%$ of the area $\left(83.26 \mathrm{~km}^{2}\right)$ with a gradient range of less than $0.3 \%$; and low zones accounted for $87 \%$ of the area $\left(25.73 \mathrm{~km}^{2}\right)$ with a gradient range of less than $0.3 \%$.

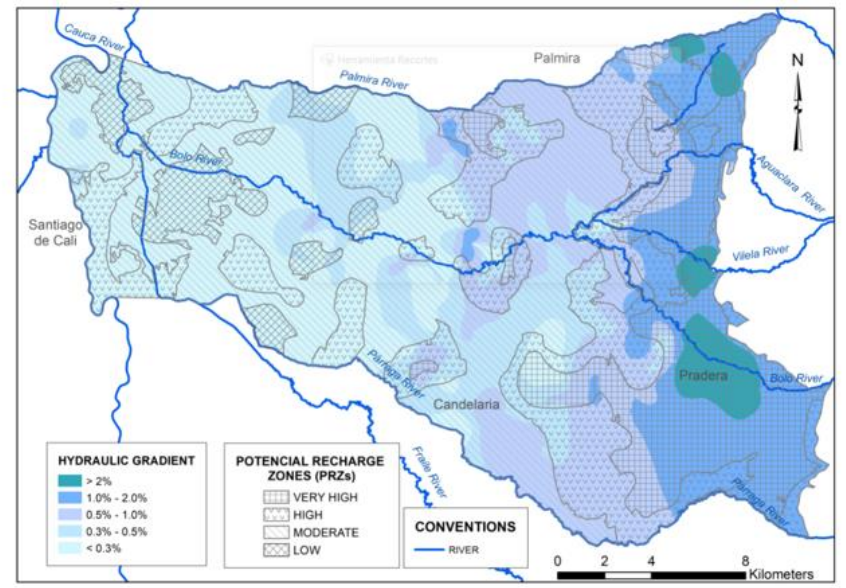

(b)

Figure 5. Validation of PRZs. (a) Relationship between the estimated PRZ and the piezometry. (b) Relationship between the estimated PRZ and the hydraulic gradient. Source: 


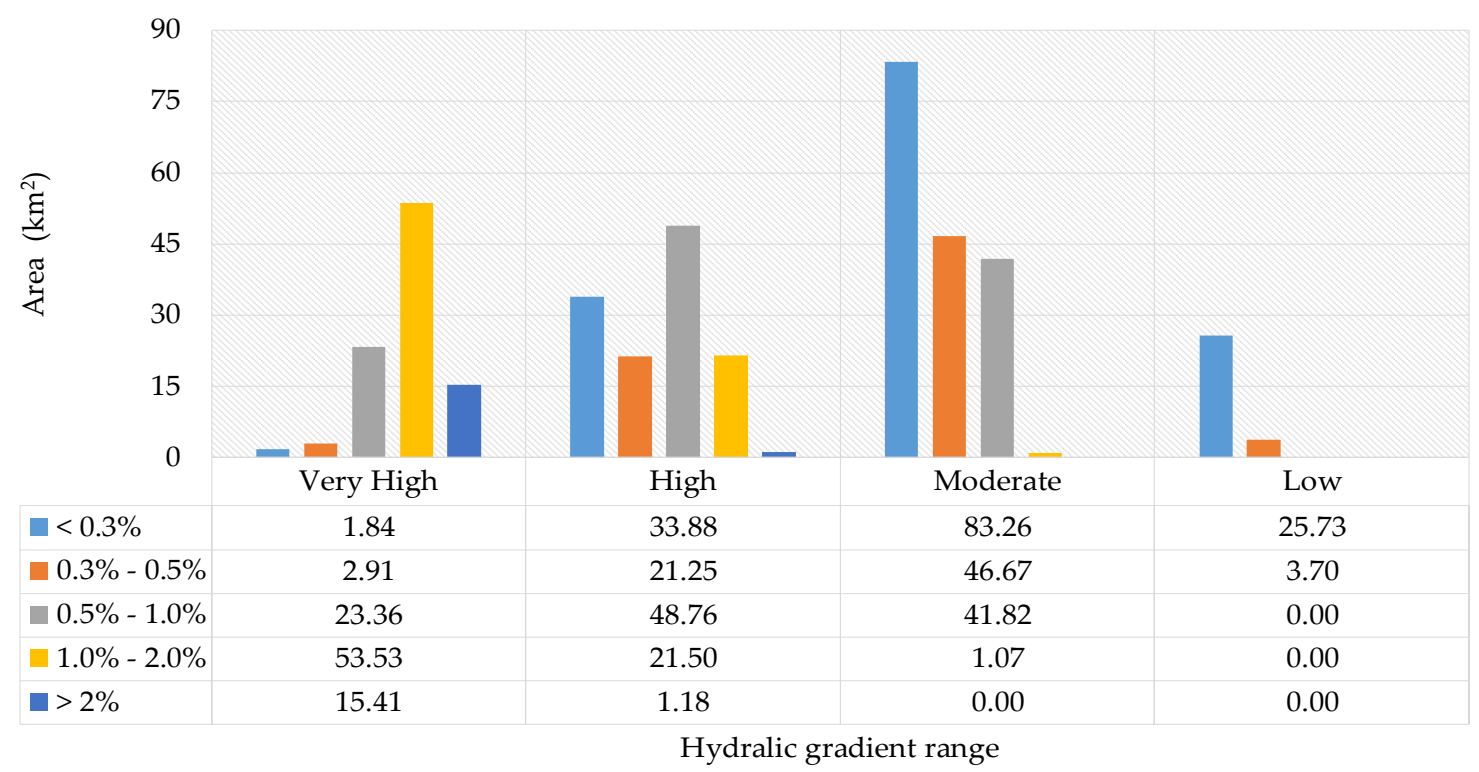

Figure 6. Distribution of estimated recharge zones by area and by type of PRZ. Source: own elaboration

Regarding the lower representativeness of areas based on the range of hydraulic gradients, the pattern of recharge potential was as follows: areas with a very high potential accounted for $2 \%(1.84$ $\mathrm{km}^{2}$ ) with a gradient range of less than $3 \%$; areas with a high potential accounted for $1 \%\left(1.18 \mathrm{~km}^{2}\right)$ with a gradient range greater than $2 \%$; and areas with moderate and low potentials had no representativeness for gradients greater than $1 \%$.
Based on a trend analysis (Table 8), it was validated that the categories classified as very high and low potentials have a defined behavior as a function of the hydraulic gradient. For the first case, there was a greater probability of finding areas with a very high recharge potential as the hydraulic gradient increased (directly proportional).

Table 8. Trend analysis of the behavior of the PRZs in relation to the hydraulic gradient range.

\begin{tabular}{cccccc}
$\begin{array}{c}\text { Potencial Recharge } \\
\text { Zones (PRZs) }\end{array}$ & \multicolumn{5}{c}{ PRZs percent in the hydraulic gradient range } \\
\hline Very high & $1,3 \%$ & $0.3 \%-0.5 \%$ & $0.5 \%-1.0 \%$ & $1.0 \%-2.0 \%$ & $>2 \%$ \\
High & $23,4 \%$ & $20,5 \%$ & $70,3 \%$ & $92,9 \%$ \\
Moderate & $57,5 \%$ & $62,6 \%$ & $36,7 \%$ & $1,4 \%$ & $0,0 \%$ \\
Low & & & & \\
Total & $17,8 \%$ & $5,0 \%$ & $0,0 \%$ & $0,0 \%$ & $0,0 \%$ \\
\hline
\end{tabular}

Source: own elaboration 
There was a $70 \%$ probability of finding areas with a very high recharge potential when the hydraulic gradient was greater than $1 \%$. The probability increased to $93 \%$ when the hydraulic gradient was greater than $2 \%$. For the second case, there was a lower probability of finding areas with a low recharge potential as the hydraulic gradient increase (inversely proportional). For the study area, the probability of occurrence of a cataloged area with a low potential was zero for gradients greater than $0.5 \%$; gradients between $0.3 \%$ and $0.5 \%$ only reached $5 \%$ probability; and for gradients lower than $0.3 \%$, the probability of occurrence was $18 \%$ (Table 8 ).

From the same trend analysis (Table 8) and based on the ranges of the hydraulic gradient, the results obtained for the study area show that there is a probability of occurrence of $100 \%$ to delimit an area with a high to very high potential of reload when the hydraulic gradient is greater than $2 \%$; the probability is $98.5 \%$ for a gradient range between $1 \%$ to $2 \%$ and $63.3 \%$ for a gradient range between $0.5 \%$ to $1 \%$ (Table 8 ). Based on these results, a proportional relationship was observed between the hydraulic gradient and the categorization of the recharge potential. The delimitation of recharge zones with a low to moderate potential was observed for hydraulic gradients below $0.5 \%$ with a probability of occurrence of $67.6 \%$; for gradients of less than $0.3 \%$, the probability was $75.3 \%$.

For a moderate to high potential, inflection occurred in the hydraulic gradient between $0.5 \%$ and $1 \%$ because a higher probability of occurrence in gradients greater than $1 \%$ were characterized as recharge areas with a high to very high potential. For areas with hydraulic gradients of less than $0.5 \%$, there was a trend toward a moderate potential, and the lower limits of the ranges corresponded to $62.6 \%$ for gradients between $0.3 \%$ to $0.5 \%$ and $57.5 \%$ for gradients of less than $3 \%$. Additionally, it was observed that for gradients greater than $1 \%$, the probability of occurrence of areas with a moderate recharge potential was less than $1.4 \%$.

\section{Discussion}

In the construction of the PRZ index, the process of recharging aquifers was addressed in a simplified way by only taking into account the physical (or intrinsic) properties in the different layers through which water must travel to recharge an alluvial aquifer. Unlike other studies $(2,5,10,12-14,28,35,36,38,45,78,80,85,86)$, this study suppressed factors external to the soil infiltration process, which can be altered by anthropogenic actions, such as land use and soil management practices, or by climatic variations and changes that affect the magnitude of the recharge but not the potential of an aquifer to be recharged. This contributes to ensuring the sustainability of ecosystems that depend on the dynamics of recharge zones. In this sense, the PRZ index was developed as a prevention tool, and it is an instrument for environmental and land use planning.

The index proposed in this study was conceptualized as an additive type of index (equal weights for all factors) and considered only the restrictions imposed by the natural environment for the recharge process. The main advantage of the proposed PRZ index is that it limits the subjectivity associated with weighted indexes, for which the assignment of weights to multiple factors by decisionmakers, panels of experts or a particular methodology can lead to different results ${ }^{(25)}$

At the end of 2019, the IDEAM ${ }^{(28)}$ presented a methodological proposal for the delimitation of PRZs at the national scale based on the development of a weighted index, which involved 5 factors: fracture density, slope, lithology, texture, coverage and land use. Unlike the PRZ index, the methodology formulated by IDEAM (28) includes parameters external to the aquifer 
system. These parameters can present anthropogenic interventions that do not modify the intrinsic potential of an evaluated area although they do modify the magnitude of the recharge. When the fracture density is considered, the methodology presented by IDEAM ${ }^{(28)}$ limits the analysis to intermontane alluvial aquifers, such as the alluvial aquifer of the Cauca River considered in this study, and takes into account the fault system underlying the alluvial sediments, which can be very thick.

Additionally, although both indices worked with the lithology factor, the IDEAM methodology ${ }^{(28)}$ only infers the porosity (primary or secondary) of the lithological predominance per chronostratigraphic unit of the geological map of Colombia. In the proposed PRZ index, the lithology is considered in greater detail because with this parameter, the lithological predominance is evaluated as a function of the textural classes in the UZs and SZs based on the records of deep wells.

In contrast, just as the hydrographic basin is considered as the unit of analysis for integrated water resources management, in this research, a hydrogeological area was considered as the unit of analysis for the definition of a PRZ. Hydrogeological areas include surface basins and regions based on geology that represent the physical environment in which the dynamics of the hydrological cycle in its underground component are developed, according to the capacity of rocks and strata to store and transmit water ${ }^{(87)}$. A hydrogeological zone responds to the geological model of the subsoil and recognizes the geometry and tectonostratigraphic boundaries of the aquifer units ${ }^{(87)}$. Different studies ${ }^{(2,5,10,12-}$ $14,28,35,36,38,45,78,80,85,86$ ) have delimited recharge zones; however, the analysis units in these studies do not follow hydrogeological zones. The delimitation of the potential zones was made based on geographic and political-administrative limits or at the level of hydrographic basins. Additionally, the recharge zones defined in these studies were not validated. Unlike this research, a validation was performed with the hydraulic gradient by plotting the piezometric surface, which is characterized by positive hydraulic potential values and divergent flow ${ }^{(27)}$.

The hydrogeological zone of the Bolo River already had zones delimited by the $\mathrm{CVC}^{(6)}$ based on local expert knowledge of the surface geology and flow system. The zones defined at that time were delimited for management purposes and included three types of zones (recharge, transition and discharge). The difference between the zones defined by the $\mathrm{CVC}^{(6)}$ and those determined in this research, is based on the baseline information scale used to estimate the zones, and the GIS methods used for analysis. The results of the CVC (6) and those presented in this study agree in terms of the location of the areas with the greatest recharge potential, which are located above the debris cones, where the hydraulic gradients are greater than $1 \%$.

\section{Conclusions}

A methodological tool was developed for the delimitation of PRZs in alluvial aquifers through the design of the additive PRZ index based on five characterization indicators that only included intrinsic parameters of the aquifer that were mutually exclusive. The index can be used to characterize a territory into four categories of recharge potential. This index is considered a methodological contribution and a tool for land use planning that involves recharge zones as a central axis in environmental management. The main advantage of the designed index is not to depend on a weight system (anthropic factor), which can vary the potential of a recharge zone. In addition, the designed methodology is flexible to be applied to other contexts. The modeler can add or remove criteria and indicators according to the type of aquifer to be evaluated. However, the current application of the designed index only allows evaluating alluvial aquifers in intermountain valleys. 
Through the implementation of the proposed PRZ index, a conceptual model was constructed for delimiting the PRZs in the hydrogeological zone surrounding the Bolo River, Colombia, where it was observed that $53 \%$ of the recharge potential was characterized as high to very high and $41 \%$ was characterized as a moderate potential. This is due to a combination of physical factors such as the depth of the first permeable layer, the lithology, the degree of confinement and the infiltration potential. In this sense, the study area can be considered to be an area of strategic importance.

Validation of the PRZs in the hydrogeological area surrounding the Bolo River was performed. Seventy-one percent of the areas with a very high recharge potential showed hydraulic gradients greater than $1 \%$. In areas with hydraulic gradients greater than $1 \%$, there was a $98 \%$ probability of finding areas characterized by a high to very high recharge potential. There was a proportional relationship between the gradient, its magnitude and the potential of the aquifer recharge zones in the context evaluated. This validation can be referenced when zoning PRZs in regions with characteristics similar to those of the study area.

\section{Acknowledgments and funding statement}

The authors thank the Vicerrectoría de Investigaciones of the Universidad del Valle, the resources of the MINCIENCIAS Scholarship Program No. 727-2015 and the Corporación Autónoma Regional delValle del Cauca (CVC) for the information provided. This work received funding from the DGIS IHE-Delft Programmatic Cooperation 2016-2020 (DUPC), grant number 106471.

\section{References}

(1) UNESCO. Informe de las Naciones Unidas sobre los recursos hídricos en el mundo. Italia: WWAP ed.; 2015. p. pp. 12.
(2) Arévalo L, Rivera J. Definición de zonas de recarga y descarga de agua subterránea a partir de indicadores superficiales: centrosur de la Mesa Central, México. Investigaciones Geográficas, Boletín del Instituto de Geografía. 2013; (81):18-32.

(3) Hendrickx JM. Groundwater Recharge. A Guide to Understanding and Estimating Natural Recharge. Journal of Environmental Quality. 1992;21(3):512512.

https://doi.org/10.2134/jeq1992.00472425 002100030036x.

(4) Kresic N. Groundwater resources: Sustainability, management, and restoration. United States: McGraw Hill Professional Ed; 2008.

(5) Matus Ó, Faustino J, Jiménez Otárola F. Metodología para la identificación participativa de zonas con potencial de recarga hídrica en subcuencas hidrográficas. Validación en la subcuenca del río Jucuapa, Nicaragua. Recursos naturales y Ambiente. 2008;55:74-82. Available from: http://hdl.handle.net/11554/6573.

(6) CVC. Plan de manejo para la protección de las aguas subterráneas en el departamento del Valle del Cauca. Cali, Colombia; 2000.

(7) Foster S, Garduño H, Karin Kemper, Tuinhof A, Nanni M, Dumars C. Protección de la calidad del agua subterránea. Definición, estrategias y establecimiento de prioridades. GW Mate briefing note series; no. 8 Washington, D.C.: World Bank Group; 2003. http://documents.worldbank.org/curated/e n/804581468313863477/Proteccion-de-lacalidad-del-agua-subterranea-definicionde-estrategias-y-establecimiento-deprioridades. 
(8) Freeze R, Cherry J. Groundwater. New Jersey: Prentice-Hall; 1979.

(9) Vélez MV. Hidráulica de aguas subterráneas. Medellín, Colombia: Facultad de Minas, Universidad Nacional de Colombia; 1992.

(10) Chowdhury A, Jha MK, Chowdary V. Delineation of groundwater recharge zones and identification of artificial recharge sites in West Medinipur district, West Bengal, using RS, GIS and MCDM techniques. Environmental Earth Sciences. 2010;59(6):1209-22. https://doi.org/10.1007/s12665-009-01109.

(11) World Bank. Protección de la calidad del agua subterránea. Guía para empresas de agua, autoridades municipales y agencias ambientales. 2nd ed. Washington: World Bank; 2007.

(12) Kumar M, Rao MS, Kumar B, Ramanathan A. Identification of aquifer-recharge zones and sources in an urban development area (Delhi, India), by correlating isotopic tracers with hydrological features. Hydrogeology journal. 2011;(19):463-74. https://doi.org/10.1007/s10040-010-0692$\mathrm{z}$.

(13) Rodríguez L. Revisión y análisis de los factores que influyen en la recarga natural del acuífero del Valle de Aguascalientes mediante sistemas de información geográfica (SIG) [Master's Thesis]. México: Universidad Autónoma de Aguas Calientes; 2016. Available from: http://hdl.handle.net/11317/620.

(14) Palacio B, Andrea P, Betancur V. Identificación de fuentes y zonas de recarga a un sistema acuifero apartir de isótopos estables del agua. Caso de estudio: bajo cauca antioqueño. Gestión y Ambiente. 2007;10(1):167-82. Available from: https://revistas.unal.edu.co/index.php/gesti on/article/view/1388

(15) CVC. Acuerdo 042 de 2010. Protección de las aguas subterráneas del Valle del Cauca. In: Grupo de Recursos Hídricos, editor. Cali, Colombia; 2010.

(16) CVC, DELTARES, IHE. Evaluación de las aguas subterráneas en condiciones climáticas extremas -ESCASEZ. Grupo de Recursos Hídricos de la CVC. Cali, Colombia; 2015.

(17) CVC. Bases de datos. Gestión del recurso hídrico subterráneo. Grupo de Recursos Hídricos. Cali, Colombia; 2018.

(18) Ingeominas, CVC. Hidrogeología del Valle del río Cauca entre Santander de Quilichao y el río Sonso. Cali, Colombia; 1971.

(19) CVC. Codificación de corrientes en las cuencas que drenan al Río Cauca y hacia el océano Pacífico, en el área de jurisdicción de la CVC, de acuerdo con los límites definidos con fines de ordenación. Cali, Colombia: Grupo de Recursos Hídricos; 2007.

(20) IGAC. Instructivo códigos para levantamiento de suelos. Bogotá, Colombia; 2014.

(21) Gómez A. Caracterización hidráulica del acuífero de la zona plana del Valle del Cauca [Master's Thesis]. Bogotá: Universidad Nacional de Colombia; 2012. Available from: https://repositorio.unal.edu.co/handle/unal /60113. 
(22) Cazau P. Categorización y operacionalización de variables. Apuntes sobre metodología de la investigación. México: Universidad Pedagógica de Durango; 2004.

(23) Villavicencio-Caparó E, Torrachi-Carrasco E, Pariona-Minaya MC, Alvear-Córdova MC. ¿Cómo plantear las variables de una investigación? Operacionalización de las variables. Revista OACTIVA UC Cuenca. 2019;4(1):9-14. https://doi.org/10.31984/oactiva.v4i1.289.

(24)

$\begin{array}{lll}\text { Reguant } \quad \text { M, } & \text { Martínez } & \text { F. } \\ \text { Operacionalización } & & \text { de }\end{array}$
conceptos/variables. Barcelona: Repositorio digital de la Universidad de Barcelona; 2014. Available from: https://n9.cl/clp0

(25) Gómez G, Grinszpun M. Capitulo 5: El uso de los índices y las tipologías en la construcción de indicadores complejos. In: Teseopress, editor. Argentina: Metodología de la investigación; 2010.

(26) Hutchinson MF. A new procedure for gridding elevation and stream line data with automatic removal of spurious pits. Journal of hydrology. 1989;106(3-4):21132. https://doi.org/10.1016/00221694(89)90073-5.

(27) Rebollo LF, Martín-Loeches M. Diez preguntas elementales sobre aguas subterráneas. Enseñanza de las Ciencias de la Tierra. 2007;15(3):240-9. Available from:

https://raco.cat/index.php/ECT/article/vie w/121181/167582

(28) IDEAM. Estudio nacional del agua 2018. Bogotá: Colombia; 2019. p. 452.
(29) Sánchez FJ. Hidrología superficial y subterránea. España: Universidad de Salamanca; 2017. 285 p. Available from: https://hidrologia.usal.es/Libro.htm

(30) Burns E. Repensar la cuenca: la gestión de ciclos del agua en el Valle de México. México: Universidad Autónoma Metropolitana y Centro para la Sustentabilidad Incalli Ixcahuicopa ed; 2009.

(31) Vélez MV, Ortiz C, Vargas MC. Las aguas subterráneas: Un enfoque práctico. Bogotá, Colombia: Ingeominas, Universidad Nacional de Colombia; 2011.

(32) Todd DK, Mays LW. Groundwater Hydrology. 3rd ed. Willey International Ed; 2005.

(33) Custodio E, Llamas R. Hidrología subterránea. 2da ed. Barcelona, España: Omega; 1996.

(34) Rushton K, Rathod K. Causes of non-linear step pumping test responses. Quarterly Journal of Engineering Geology and Hydrogeology. 1988;21(2):147-58. https://doi.org/10.1144/GSL.QJEG.1988.0 21.02.04.

(35) Oikonomidis D, Dimogianni S, Kazakis N, Voudouris K. A GIS/remote sensing-based methodology for groundwater potentiality assessment in Tirnavos area, Greece. Journal of Hydrology. 2015;525:197-208. https://doi.org/10.1016/j.jhydrol.2015.03.0 56.

(36) Guzmán A, Díaz A. Identificación de las área de recarga acuífera y zonas de protección de los manantiales del canton central de Cartago. En: IX Congreso Nacional de Ciencias Exploraciones fuera y dentro del aula Cartago. Cartago, Costa 
Rica: Instituto Tecnológico de Costa Rica; 2007.

(37) Castro-Brenes J, Martinez S, Leal-Tijerino S, Aguirre J. Plan de manejo y conservación de zonas con potencial de recarga hídrica, micro cuenca El Espinal, Pueblo Nuevo. Managua, Nicaragua: Universidad Nacional Agraria; 2011.

(38) García M. Determinación de las zonas potenciales de recarga hídrica en las subcuencas de los ríos Tacó y Shusho, Municipio de Chiquimula, Departamento de Chiquimula [Bachelor's Thesis]. Guatemala: Universidad de San Carlos; 2010. Available from: http://www.repositorio.usac.edu.gt/2933/1 /19\%20A\%20T-1362-690.pdf

(39) Martínez S, Sastre A (ed). Estudios en la Zona No Saturada En: Vol.XII trabajos presentados en las XII Jornadas de investigación en la Zona No Saturada del Suelo, Alcalá de Henares. España: Universidad de Alcalá; 2015.

(40) del Río J, Navarro J. Aproximación al conocimiento de la infiltración a través del análisis dimensional. Ecología. 2006(20):471-92.

(41) Manso JM, Hevia JN. Infiltración y grupos hidrológicos de suelos en las laderas de los páramos (Valladolid). Cuadernos de investigación geográfica. 2012(38):13153. https://doi.org/10.18172/cig.1279.

(42) Horton RE. An approach toward a physical interpretation of infiltration-capacity. Soil science society of America journal. 1941;5(C):399-417.

https://doi.org/10.2136/sssaj1941.0361599 $50005000 \mathrm{C} 0075 \mathrm{x}$.
(43) Parr JF, Bertrand AR. Water infiltration into soils. En: Advances in Agronomy. Elsevier; 1960. p. 311-63.

(44) Gisbert JM, Ibañez S, Moreno H. La textura del suelo. España: Universidad Politécnica de Cataluña; 2010. Available from: http://hdl.handle.net/10251/7775.

(45) da Costa AM, de Salis HHC, Viana JHM, Leal Pacheco FA. Groundwater Recharge Potential for Sustainable Water Use in Urban Areas of the Jequitiba River Basin, Brazil. Sustainability. 2019;11(10):2955. https://doi.org/10.3390/su11102955.

(46) Llamas MR, Fornes JM, Hernandez-Mora N, Cortina LM, Azcoiti JMF. Aguas subterráneas: Retos y oportunidades. Madrid: Mundi-Prensa; p. 529.

(47) Braun GM, Levine NS, Roberts SJ, Samel AN. A geographic information systems methodology for the identification of groundwater recharge areas in Waukesha County, Wisconsin. Environmental \& Engineering Geoscience. 2003;9(3):26778. https://doi.org/10.2113/9.3.267.

(48) Vasconcelos VV, Martins Junior P, Hadad RM. Methodology for rapid assessment of aquifer recharge areas. Geologia USP Série científica. 2013;13(2):69-96. https://doi.org/10.5327/Z1519874X2013000200005.

(49) Feitosa F, Filho J, Feitosa E, Demetrio G. Geoprocessamento em Ambiente SIG Aplicado á Hidrogeologia. In: Hidrogeologia: conceitos e aplicações. 3rd ed. Rio de Janeiro, Brasil: CPRM, LABHID; 2008. p. 293-322.

(50) Wickel BAJ. Procesos eco-hidrológicos y servicios ambientales. In: Curso Centroamericano de Servicios 
Hidrologicos. Guatemala: World Wildlife Fund (WWF), Conservation Science Program; 2009.

(51) Moreti, D., Carvalho, M., Mannigel, A., y Medeiros, L. Importantes características de chuva para a conservação do solo e da água no município de São Manuel (SP). Revista Brasileira de Ciência do Solo. 2003; 27: 713-725. https://doi.org/10.1590/S010006832003000400016

(52) USDA, SCS. Section 4: Hydrology. In: National engineering handbook. Washington: USDA; 1972.

(53) Tucci C. Hidrologia: ciência e aplicação. 4th ed. Porto Alegre, Brasil: UFRGS ed; 2009.

(54) Ottoni Filho T. Uma classificação físicohídrica dos solos. Revista Brasileira de Ciência do Solo. 2003;27(2):211-22. https://doi.org/10.1590/S010006832003000200001 .

(55) Gomes MAF, Spadotto CA, Pessoa MC. Avaliação da vulnerabilidade natural do solo em áreas agrícolas: subsídio à avaliação do risco de contaminação do lençol freático por agroquímicos. Pesticidas: revista de ecotoxicologia e meio ambiente. 2002;12:169-179. http://dx.doi.org/10.5380/pes.v12i0.3158.

(56) Aller L, Kerr RS. DRASTIC: a standardized system for evaluating ground water pollution potential using hydrogeologic settings. Kerr RS (ed). Worthington, Ohio: EPA; 1985.

(57) Rawls WJ, Brakensiek DL, Saxtonn K. Estimation of soil water properties. Transactions of the ASAE. 1982;25(5):1316-20. https://doi.org/10.13031/2013.33720.
(58) Hearne GA, Wireman M, Campbell AS, Turner S, Ingersoll GP. Vulnerability of the uppermost groundwater to contamination in the Greater Denver area, Colorado. Denver, Colorado: US Department of the Interior, US Geological Survey ed; 1995. https://doi.org/10.3133/wri924143.

(59) Berg RC, Kempton JP, Cartwright K. Potential for contamination of shallow aquifers in Illinois. Illinois: Illinois State Geological Survey, Prairie Research Institute; 1984.

(60) Moore J. SEEPAGE: a system for early evaluation of the pollution potential of agricultural ground water environments. Geology Technical Note 5. Chester, Pennsylvania: U.S. Department of Agriculture, Soil Conservation Service, Northeast National Technical Center; 1990.

(61) Cates KJ, Madison FW. Soil survey of Pepin County, Wisconsin. Wisconsin: USDA, NRCS; 1990.

(62) Lemme G, Carlson C, Khakural B, Knutson L, Zavesky L. Aquifer contamination vulnerability maps: a water resource protection planning tool. Lake Poinsett Pilot Project Plant Science Department, South Dakota State University, USDA - Soil Conservation Service, Plant Science Department Pamphlet 18; 1989.

(63) Blanchard PJ. Assessments of aquifer sensitivity on Navajo Nation and adjacent lands and ground water vulnerability to pesticide contamination on the Navajo Indian Irrigation Project, Arizona, New Mexico and Utah. Albuquerque, New Mexico: SGS; 2002. https://doi.org/10.3133/wri024051. 
(64) US EPA. Guidelines for Groundwater Classification under The EPA Groundwater Protection Strategy (draft). Washington: EPA; 1988.

(65) Evans BM, Myers WL. A GIS-based approach to evaluating regional groundwater pollution potential with DRASTIC. Journal of Soil and Water Conservation. 1990;45(2):242-5.

(66) Farquharson F, Mackney D, Newson M, Thomasson A. Estimation of run-off potential of river catchments from soil surveys. Special Survey. UK: Technical Monograph No.11 UK Soil Survey ed; 1978.

(67) Boorman D, Hollis JM, Lilly A. Hydrology of soil types: a hydrologically-based classification of the soils of United Kingdom. UK: Institute of Hydrology; 1995.

(68) D'Andréa, A., Silva, M., Curi, N., y Ferreira, M. Atributos de agregação indicadores da qualidade do solo em sistemas de manejo na região dos cerrados no sul do Estado de Goiás. Revista Brasileira de Ciência do Solo. 2002; 26 (4): 1047-1054. https://doi.org/10.1590/S010006832002000400022 .

(69) Bruijnzeel LA. Hydrological functions of tropical forests: not seeing the soil for the trees? Agriculture, ecosystems \& environment. 2004;104(1):185-228. https://doi.org/10.1016/j.agee.2004.01.015

(70) Brassington R. Field hydrogeology. Warrington, UK: John Wiley \& Sons Ltd; 2017.

(71) Chapman MJ, Schlegel M, Huffman BA, McSwain KB. Hydraulic gradients in recharge and discharge areas and apparent groundwater age date from the characterization of multiple regolithfractured bedrock groundwater reserch stations in Norrth Carolina. In: Proceedings of the 2007 Georgia Water Resources Conference. Athens, Georgia: The University of Georgia; 2007. Available from: http://hdl.handle.net/1853/48252.

(72) Feitosa F, Filho J, Feitosa E, Demetrio G. Importância da Água Subterrânea. In: Hidrogeologia: conceitos e aplicações. 3rd ed. Rio de Janeiro, Brasil: CPRM, LABHID; 2008. p. 13-27.

(73) Feitosa F, Filho J, Feitosa E, Demetrio G. A água subterrânea no Brasil. In: Hidrogeologia: conceitos e aplicações. 3rd ed. Rio de Janeiro, Brasil: CPRM, LABHID; 2008. p. 31-47.

(74) US EPA. Ground Water Resource Assessment. Washington: U.S. Environmental Protection Agency, Office of Groundwater and Drinking Water; 1993.

(75) Dalh M, Hinsby K. GSI typologyTypology of Groundwater/Surface interaction. In: Unesco, editor. EU Groundwater Policy Developments Conference; Paris, France: 2008. p. 146156.

(76) CETESB. Drenagem Urbana-Manual de Projeto. São Paulo, Brasil: CETESB/ASCETESB; 1986. p. 468.

(77) Azooz R, Arshad M. Soil infiltration and hydraulic conductivity under long-term notillage and conventional tillage systems. Canadian journal of soil science. 1996;76(2):143-52. https://doi.org/10.4141/cjss96-021. 
(78) Mogaji K, Omosuyi G, Adelusi A, Lim H. Application of GIS-based evidential belief function model to regional groundwater recharge potential zones mapping in hardrock geologic terrain. Environmental Processes. 2016;3:93-123. https://doi.org/10.1007/s40710-016-01266.

(79) DeLuca TH, Johnson P. RAVE, Relative Aquifer Vulnerability Evaluation. In: An On-farm Scoring System to Evaluate Aquifer Vulnerability to Pesticide Contamination: Technical Bulletin 90-01. Montana Department of Agriculture, Environmental Management Division; 1990.

(80) CORANTIOQUIA. Estudio de zonas de recarga y acuíferos del Valle de Aburra. Medellín, Colombia: Centro de Investigaciones Ambientales y de Ingeniería (CIA), Grupo de Ingeniería y Gestión Ambiental; 2002.

(81) López-Geta JA, Fornés-Ascoiti JM, Ramos-Gonzalez G, Villarroya-Gil F. Las aguas subterráneas, un recurso natural del subsuelo. Madrid: Instituto Minero y Geológico de España, Fundación Marcelino Botín; 2009.

(82) Kistinger GM, Prieur JP, Rowley PD, Dixon, GL. Characterization of streams and springs in the Snake Valley area, Utah and Nevada. Geology and Geologic Resources and Issues of Western Utah. 2009(38):299-324.

(83) Fetter C. Applied Hydrogeology. 4th ed. New Jersey: Prentice Hall; 2001. 615 p.

(84) Karamouz M, Ahmadi A, Akhbari M. Groundwater hydrology - Engineering, planning and management. 2nd ed. Boca Ratón: CRC Press Taylor \& Francis Group; 2020. 778 p.

(85) Rushton K. Numerical and conceptual models for recharge estimation in arid and semi-arid zones. In: Simmers I, eds. Estimation of natural groundwater recharge: Springer; 1988. p. 223-38.

(86) Vargas O. Zonas hidrogeológicas homogéneas de Colombia. Boletín Geológico y Minero. 2005;117(1):47-61. 